\title{
Results of studying the effects of biological products on accelerating the decomposition of the crop tailings
}

\author{
I.Yu. Bogdanchikov ${ }^{1 *}$, N.V. Byshov ${ }^{1}$, A.N. Bachurin ${ }^{1}$, M.A. Esenin ${ }^{1}$, and M.A. Tkacheva ${ }^{2}$ \\ ${ }^{1}$ Ryazan State Agrotechnical University, 390044 Ryazan, Russia \\ ${ }^{2}$ Samara University, 443086 Samara, Russia
}

\begin{abstract}
The article presents investigations aimed at addressing issues of utilization of the tailings of the crop as a fertilizer. It is known that the by-products of crop production left on the field interfere with the subsequent agricultural operations, and when used as a fertilizer it has a long decomposition period, which is accompanied by putrefactive processes with the release of phenolic compounds which inhibit subsequent plants. To accelerate the process of humification of plant residues, nitrogen-containing fertilizers are used, but recently biological preparations have become widespread, allowing the grain to be completely decomposed in 3-4 months. The authors propose a design of the machine that allows combining the operations of grinding the tailings of the crop with the introduction of bio preparations to speed up the decomposition process. The article presents the results of this machine field tests using various bio preparations: Agrinos 1, Sterniphag SP, humic preparation Ecorost and Biocomplex BTU. According to the linen method, the effect of the preparations on the activity of cellulose-decomposing bacteria was assessed. The dynamics of the activity of biological preparations was not linear and was largely dependent on weather conditions. The hotter temperature and the absence of abundant precipitation in August - September 2018 did not contribute to the active work of the soil biota and in the first report period the best decomposition of linen was in the variant with Biocomplex BTU and Sterniphag, respectively 3.6 and $3.3 \%$. On the 236th day of the experiment, the picture changed and the variants with Agrinos 1 and Ecorost showed the best performance, the decomposition was 21.2 and $21.9 \%$, respectively.
\end{abstract}

\section{Introduction}

Issues of utilization of crop by-products are relevant, as they are aimed at solving several important tasks at once:

- release the field for other machine-tractor units for the smooth implementation of subsequent technological operations;

- green production and increasing soil fertility;

- energy saving production.

Perhaps the task of improving fertility [1-6] is one of the highest priorities, because the health of the entire population of the Earth depends on it. It is known that a number of factors influence human health: heredity, which accounts for $20 \%$ and human lifestyles $-80 \%$, of which $57 \%$ are the quality of food consumed. As Hippocrates said: "We are what we eat!" It is known that any product consumed by humans for food has the path starting from the soil and finally returning to it [7, 8]. It is also known that during the formation of the crop, nutrients are removed from the soil, and their deficit must be replenished. Taking into account the fact that the tailings of the crop is $2 / 3$ part of the total biological yield (1/3 part is in the grain part), the use of crop by-products as a fertilizer will reduce the negative impact on the soil by $40-45 \%$. It is known that straw is a source of organic matter and 1 ton of it contains on average $2 \mathrm{~kg}$ of nitrogen, $2.3 \mathrm{~kg}$ of phosphorus, $10.3 \mathrm{~kg}$ of potassium, $3.2 \mathrm{~kg}$ of calcium, $1 \mathrm{~kg}$ of magnesium and a number of trace elements. They are mostly accumulated in the tailings of the crop and participate in the formation of the soil fertile layer - humus.

Within the framework of the research subject and under the order of the Ministry of Agriculture of the Russian Federation in 2018-2019 the authors studied possibilities to improve the process of tailing utilization. The studies involved a newly developed machine "Unit for utilization of the tailings of the crop as a fertilizer" (AdU NGP (Figure 1)) [9] and various biological preparations and humic products. AdU NGP works on a straw roll, picks up the plant material, grinds it with simultaneous treatment with a working solution of preparations, accelerating the decomposition process, and distributes the ready for use fertilizer evenly over the field surface. The optional incorporation into soil is possible. Structurally, this machine can be divided into three main elements:

1) a complex to prepare the tailings to be used as a fertilizer, which is a serial cutter-shredder, additionally equipped with a supply system for the working solution of the preparation, accelerating the decomposition of plant material;

\footnotetext{
* Corresponding author: cmy62.rgatu@ mail.ru
} 
2) a module for differential introduction of the working solution. It consists of a scanning device (it is located in front of the tractor in front of the counterweights at a distance of $1.0-1.2 \mathrm{~m}$ from the field surface and is a frame with three range measuring

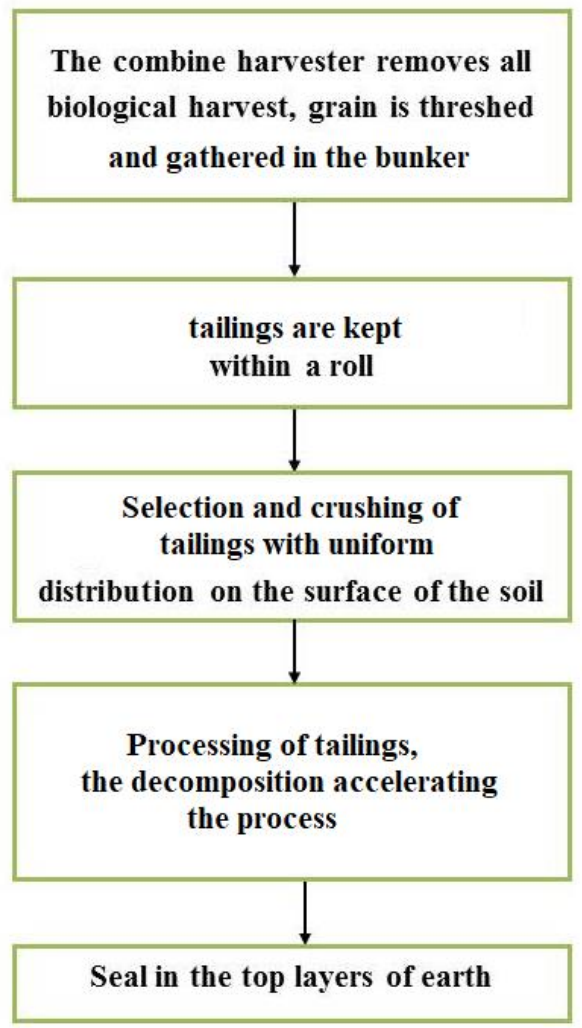

Fig. 1. The unit to utilize the tailings of the crop as a fertilizer

Before starting work, the machine operator needs to set the range scopes of the scanning device so that one of them measures the distance to the roll in the central part (top), and the other two do it along its edges. The values of the width of the roll and its density are set in the analytical unit (located in the tractor cabin) manually. Thus, the value of the height of the roll is determined automatically by the following expression:

$$
H=\frac{H_{1}-H_{2}}{2}-H_{c}
$$

where $H_{1}, H_{2}$ - distance from the range scope to the soil along the edge of the roll, $\mathrm{m} ; H_{c}$ - distance from the range scope to the central part of the roll, $\mathrm{m}$.

The studies took place on the experimental field of STIC "Agrotechnopark", Ryazan district of Ryazan region in August 2018. The following preparations were studied:

- Agrinos 1 (1-2 1/ha) is a bacterial fertilizer containing more than 80 strains of microorganisms of various families, bacteria of the Azotobacter vinelandii group $1 / 5 \times 10^{7} \mathrm{KUO} / \mathrm{ml}$ and Clostridium pasteurianum $1 / 5 \times 10^{7} \mathrm{KUO} / \mathrm{ml}$. When applied to the soil, it stimulates the formation of highly effective microbial systems (complexes of interactions of the plant root system with soil biota). The bacteria contained in Agrinos-1 absorb atmospheric nitrogen, participate in the systems installed on it (laser or ultrasound)) an analytical unit and an actuator (made in the form of a pressure regulator);

3) a complex to embed the finished fertilizer into the soil (made in the form of a disk tool).

\section{The unit to utilize tailings as fertilizers (ADA NChU)}

1 - scanner;

2 - analytical block;

3 - actuator;

4 - capacity for working solution;

5 - forsunochny stage;

6 - a complex for seal of ready fertilizer to the soil.

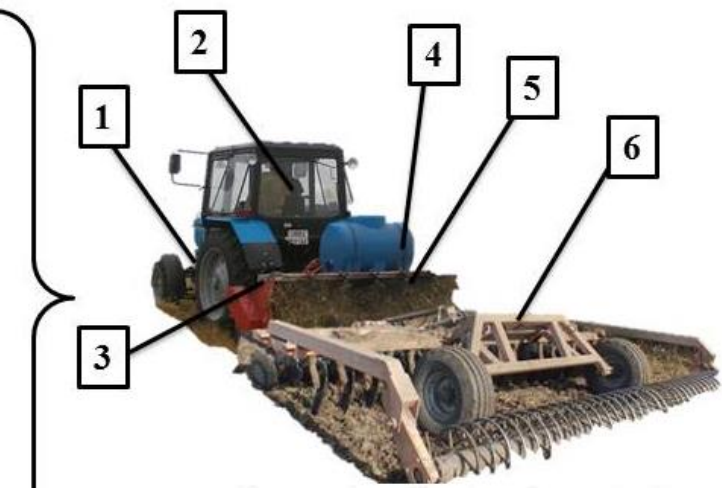

mobilization of phosphorus, potassium, calcium, sulfur and zinc, and work even with high salinity of soils, which is especially important for the southern regions. In soil, microorganisms from Agrinos-1 interact with plant roots, and they, in turn, secrete various polysaccharides, which, as a food for bacteria, contribute to the development of beneficial microflora.

Sterniphag SP (80 g/ha) is a biofungicidecellulolytic, belonging to the group of soil biological fungicides and is intended for the decomposition of soil residues of various crops (cereals, sunflowers, corn, sugar beets, etc.). The composition of the product includes spores of fungus Trichoderma harzianum BKM F-4099D (titer $10^{10} \mathrm{CFU} / \mathrm{g}$ ) and useful soil microflora. Spores of fungus Trichoderma harzianum has fungicidal and cellulolytic activity. It suppresses a wide range of phytopathogens, primarily root rot, as well as pathogens of leaf and spike infections.

- Ecorost humic preparation $(0.4 \mathrm{l} / \mathrm{ha})$ is a liquid humic fertilizer of a dark brown color, based on humic acids, odorless, $\mathrm{pH}$ neutral (6.5-7.5), active substance content up to $70 \mathrm{~g} / \mathrm{l}$ of humic acids. It is intended for processing crops (or straw) with subsequent cultivation in the soil in order to restore fertility, as well as for soil restoration. They also convert heavy metals and other harmful or radioactive elements, including toxic industrial waste and environmentally hazardous 
chemicals, into an inert, inaccessible to plants form, increasing the ecological properties of the soil. The products are environmentally friendly.

- Biocomplex BTU (1 $1 / \mathrm{ha})$ is a universal microbiological fertilizer, which is specially designed for the decomposition of post-harvest residues of corn, sunflower and other agricultural crops to improve the soil and prevent its degradation. It is a cream to brown liquid with a faint specific odor. The composition includes bacteria-antagonists of fungi and bacteria pathogenic for plants. The total number of viable effective microorganisms is not less than $1.0 \times 10^{8}$ $\mathrm{CFU} / \mathrm{cm}^{3}$, phosphorus, potassium mobilizing and nitrogen-fixing microorganisms, saprophytic fungi, biologically active substances: biofungicides, enzymes, polysaccharides, phytohormones, vitamins, amino acids, macro- and microelements.

The total area of the experimental field was 12 hectares, the crop was winter wheat, the entire crop was harvested with a combine harvester (Palesse GS 1218), the grain was threshed and collected in a bunker, and the tailings was left windrow and then it was utilized by the developed AdU NGP machine.

The field was divided into 5 equal areas. On one of them tailings were embedded into the soil without treatment with a biological preparation, on others the tailings were treated with the studied preparations.

\section{Results}

The swath left by the combine harvester was investigated. It was a semi-elliptical cylinder whose height corresponded to the length of the swath, a larger radius of the base corresponded to half the width of the swath $(1.6 \pm 0.05 \mathrm{~m})$, and a smaller radius corresponded to the height of the swath $(0.39 \pm 0.04 \mathrm{~m})$. Measurements were made using a profiler (manually), $1.6 \mathrm{~m}$ long, with installed gauges at a pitch of $0.2 \mathrm{~m}$ and the total number of rails was 9 (Figure 2).

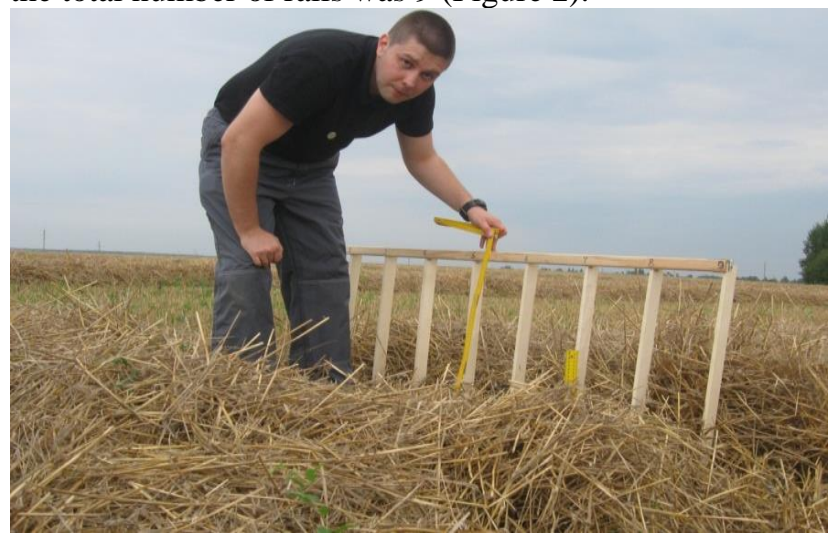

Fig. 2. Measurement of the tailings swath profile

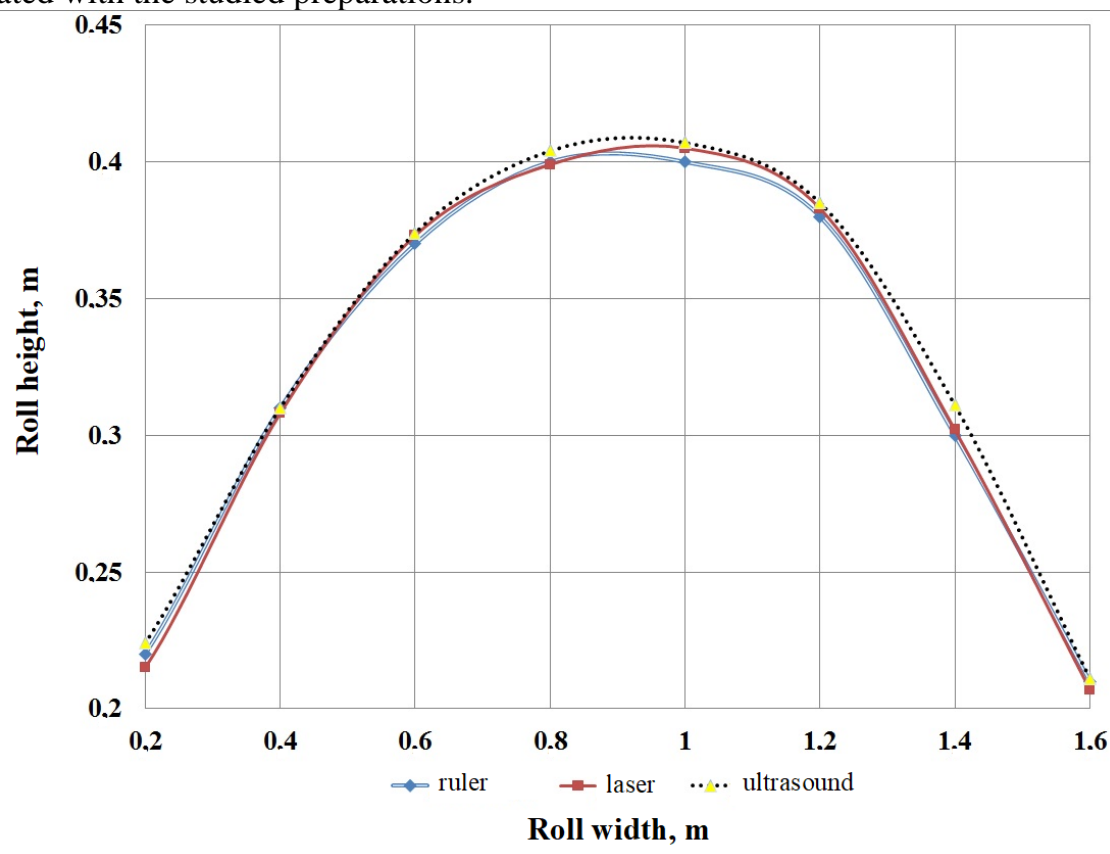

Fig. 3. Tailings roll profile measured by laser, ultrasonic range scopes and control ruler

Figure 3 shows the roll profile obtained by scanning it using laser and ultrasonic range scopes and a control ruler. The measurements were carried out at a height of 1 meter from the surface of the field, in cloudless weather when the sun was at its zenith.

One can see that the deviations in the measurement of the roll profile do not exceed $1 \%$ at the top of the roll and $5 \%$ at the edges, so it is possible to conclude that the use of laser and ultrasonic range scopes is permissible in the design of scanning device AdU NChU.
The principle of operation of any range scope is to measure the response time of the signal (i.e., the time from the moment the signal was emitted until it was read by the receiving sensor - the "receiver"). When the machine and tractor unit move along the swath with a speed of $V p$, the scanning unit (for example, equipped with ultrasonic range scopes) emits an audio signal with a frequency of $40 \mathrm{kHz}$. The reflected signal travels a distance of $2 \mathrm{H}$ at a speed of $340.29 \mathrm{~m} / \mathrm{s}$ [9] for some time $t$, however, during the same time, the frame of the scanning device moves to a distance $S p=V p * t$, which 
imposes a limit on the upper permissible operating speed of the machine-tractor unit.

Theoretical studies have shown that ultrasonic range scopes will have the lowest speed of reflected signals, so the worst-case scenario was simulated on a computer. It was found that the maximum displacement of the scanning device in time $t$ (we mean the time in which the range scope's sound signal travels a distance of $2 H$ ) does not exceed $0.02 \mathrm{~m}(2 \mathrm{~cm})$. It indicates a possibility of using ultrasonic range scopes at operating speeds of not more than $2.78 \mathrm{~m} / \mathrm{s}(10 \mathrm{~km} / \mathrm{h})$, which corresponds to the range of operating speeds $(7-8 \mathrm{~km} / \mathrm{h})$ of the proposed machine.

Then, the initial parameters were entered into the analytical block of AdU NGP:

- swath width;

- density of the swath;

- swath moisture;

- norm of applying the working solution of the studied preparation.

Further, the regulation of the rate of application of the working solution was carried out by changing the working pressure automatically on the incoming information from the scanning device:

$$
P_{s p r}=\frac{N^{2} \cdot m_{\mathrm{NGP}}^{2} \cdot \rho_{\mathrm{w} \mathrm{s}}}{2 \cdot \mu^{2} \cdot \mathrm{s}_{\mathrm{n}}^{2} \cdot \mathrm{n}_{\mathrm{n}}^{2} \cdot \mathrm{t}^{2}}
$$

where $\mu$ is the nozzle discharge coefficient, $\mu=0.05 \ldots$ $0.8 ; n$ is the number of nozzles installed on AdU NGP, pcs; $S_{n}^{n}$ is the nozzle area, $\mathrm{m}^{2} ; P_{s p r}$ is the pressure of the working solution in the nozzle at the time of spraying, $\mathrm{Pa} ; t$ is time, $\mathrm{s} ; m_{N G P}$ is the mass of NGP entering AdU NGP, $\mathrm{kg} ; N$ is the application rate of the working solution, $\mathrm{kg} / \mathrm{ha} ; \rho_{\mathrm{w}}$ is the density of the working solution, $\mathrm{kg} / \mathrm{m}^{3}$.

The mass of tailings based on the shape of a semielliptical cylinder can be estimated as:

$$
m_{N G P}=V_{N G P} \cdot \rho=\frac{\pi \cdot B_{s w} \cdot H \cdot V_{P} \cdot t \cdot \rho}{4}
$$

where $V_{N G P}$ is the volume of the tailings that entered the device during time $t, \mathrm{~m}^{3} ; \rho$ is the density of the tailings of the crop, $\mathrm{kg} / \mathrm{m}^{3} ; B_{s w}$ is the swath width, $\mathrm{m} ; H$ is the swath height, $\mathrm{m} ; V_{P}$ is the speed of the machine-tractor unit, $\mathrm{m} / \mathrm{s} ; \pi \approx 3.14$.

In the process of AdU NGP operation, its operational parameters were recorded. The working speed was 7-8.5 $\mathrm{km} / \mathrm{h}$ with an hourly capacity of up to $5.5 \mathrm{ha} / \mathrm{h}$. The stock of the working stroke in terms of the capacity of the process tank was $3,000 \pm 50 \mathrm{~m}$. The digestibility of the working solution was $91.7 \%$ [10]. The NGP grinding quality met agrotechnical requirements, so the mass fraction of straw particles with a length of up to $100 \mathrm{~mm}$ was more than $90 \%$.

After incorporating the tailings into the upper layers of the soil (no more than $0.15 \mathrm{~m}$ of depth), linens were laid on each of the sections (on $0-0.3 \mathrm{~m}$ soil layer). Plates were removed in 3 stages:

1) after 48 days;
2) after 86 days (soil samples were taken for complex chemical analysis);

3) after 236 days following overwintering (soil samples were taken for complex chemical analysis).

The results of the decomposition of linens are presented in Table 1 and as a graph in Figure 3. Before being embedded in the soil, each linen was weighed and after the samples were removed, the weight loss from the initial sample was estimated.

The dynamics of the activity of biological products was non-linear (Figure 3) and was largely dependent on weather conditions. The hotter temperature and the absence of abundant precipitation in August - September 2018 did not contribute to the active work of the soil biota and in the first report period the best decomposition of linens was in the variant with Biocomplex BTU and Sterniphag, respectively 3.6 and $3.3 \%$. The variant with Ecorost was inferior to these variants. The decomposition here was fixed at $2.5 \%$. The variant with Agrinos 1 preparation and the control have practically no decomposition of the biological mass. A scanning device with ultrasonic range finders showed reliable operation with a deviation of no more than $\pm 4 \%$.

Precipitation at the end of September and at the beginning of October, even with a decrease in temperature, accelerated the processes of reproduction of soil microorganisms and, in particular, cellulosedecomposing bacteria. Under these conditions, Ecorost, which contains humic and fulvic acids, helped soil microorganisms in their vital processes most effectively. The dynamics of decomposition of plant residues increased by more than three times.

After overwintering (236 days of the experiment), the best decomposition rates were shown by the variants with Ecorost and Agrinos 1, respectively, by $21.91 \%$ and $21.2 \%$.

The results of a complex chemical analysis of the soil after 236 days of the experiment are presented in Table 2. Table 3 presents parameters of the content of trace elements in the soil on the 236th day of the experiment.

To date, spring barley of Vladimir variety has been sown on the test field (sowing took place on April 23, 2019). Figure 4 shows a fragment of the experimental field, 44 days after sowing. Aerial photography was carried out using a dji phantom 4 pro quadrocopter with a standard $20 \mathrm{MPi}$ camera and an additional Parrot Sequoia multispectral camera from a height of 50-60 meters and it showed that shoots develop evenly, but in some places there is a lack of nitrogen.

Table 1. Parameters of decomposition of linens, \% left from the original sample.

\begin{tabular}{|c|c|c|c|c|}
\hline Preparation & $\begin{array}{c}\text { Agrinos, } \\
1\end{array}$ & $\begin{array}{c}\text { Sterniphag } \\
\text { SP }\end{array}$ & Ecorost & $\begin{array}{c}\text { Biocomplex } \\
\text { BTU }\end{array}$ \\
\hline $\begin{array}{c}\text { Sample } \\
\text { (48 days) }\end{array}$ & 99.48 & 96.70 & 97.50 & 96.35 \\
\hline $\begin{array}{c}\text { Second sample } \\
\text { (86 days) }\end{array}$ & 95.30 & 87.40 & 79.40 & 86.00 \\
\hline $\begin{array}{c}\text { Third sample } \\
\text { (236 days) }\end{array}$ & 78.80 & 81.90 & 78.09 & 85.07 \\
\hline
\end{tabular}




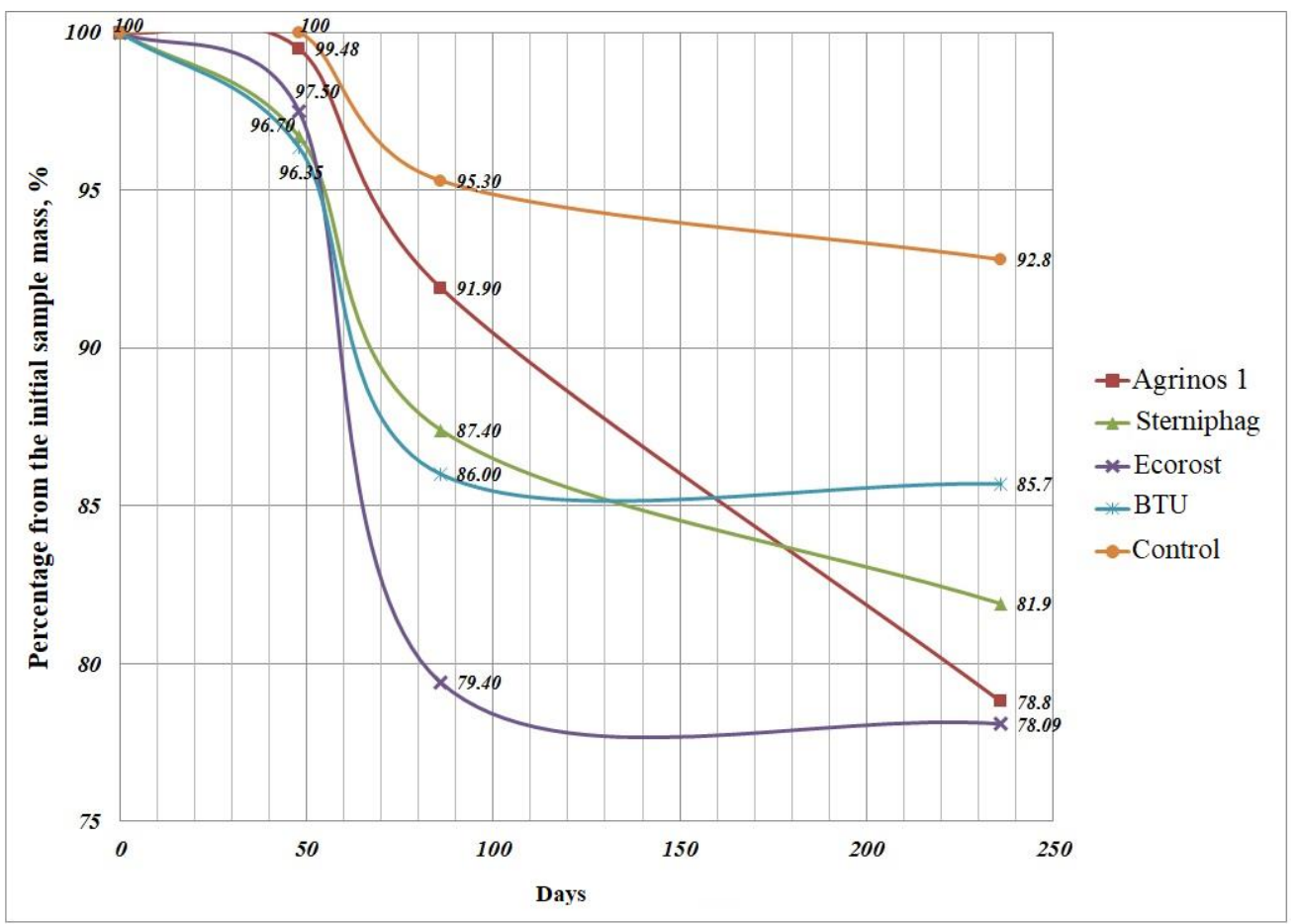

Fig. 3. The rate of decomposition of linen samples

Table 2. Soil parameters, on day 236 of the experiment

\begin{tabular}{|l|c|c|c|}
\hline \multicolumn{1}{|c|}{ Parameters } & \multirow{2}{*}{ Control } & Agrinos 1 & Ecorost \\
\hline pH (salt extract) & 5.2 & 5.8 & 5.2 \\
\hline $\mathrm{K}_{2} \mathrm{O} \mathrm{mg} / \mathrm{kg}$ of soil & 135 & 181 & 186 \\
\hline $\mathrm{P}_{2} \mathrm{O}_{5} \mathrm{mg} / \mathrm{kg}$ of soil & 178 & 231 & 201 \\
\hline $\mathrm{NO}_{3} \mathrm{mg} / \mathrm{kg}$ of soil & 3.36 & 6.04 & 9.16 \\
\hline Organic matter, $\%$ & 2.72 & 2.76 & 2.71 \\
\hline
\end{tabular}

Table 3. The content of trace elements in the soil on the 236th day of the experiment

\begin{tabular}{|l|c|c|c|c|}
\hline Parameters Variant & Control & $\begin{array}{c}\text { Agrinos } \\
1\end{array}$ & $\begin{array}{c}\text { Sterniphag } \\
\text { SP }\end{array}$ & Ecorost \\
\hline Zinc $(\mathrm{Zn}), \mathrm{mg} / \mathrm{kg}$ of soil & 1.09 & 1.33 & 1.33 & 0.96 \\
\hline Copper $(\mathrm{Cu}), \mathrm{mg} / \mathrm{kg}$ of soil & 6.05 & 7.89 & 6.84 & 6.58 \\
\hline Boron $(\mathrm{B}), \mathrm{mg} / \mathrm{kg}$ of soil & 0.60 & 0.80 & 1.02 & 0.63 \\
\hline
\end{tabular}

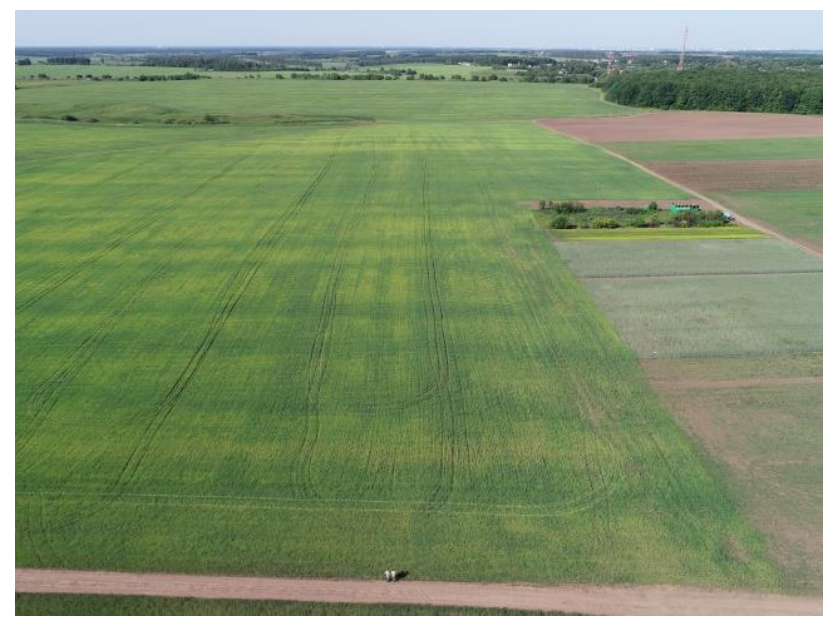

Fig. 4. Fragment of the experimental field on the 44th day of sowing

\section{Conclusion}

Biological micro-fertilizers had some positive effect on the content of mobile forms of potassium and phosphorus compared with the control. With the exception of BTU complex with potassium availability, all other preparations increased the content of soil macronutrients from medium to high values. It is possible that a similar situation with potassium in the variant with BTU complex is related to the fact that this preparation contains potassium-mobilizing bacteria that convert labile forms into easily-available, but under the condition that they pass through a certain time exposure, longer than was used in our experiment.

The content of mobile nitrate nitrogen, in contrast, was significantly higher in the variants with preparations intended for soil and foliar use. On average, the nitrogen content increased by $79.16 \%$ and amounted to $18.74 \mathrm{mg} / \mathrm{kg}$ of soil, the potassium content also increased by $24.82 \%$ (amounted to $168.5 \mathrm{mg} / \mathrm{kg}$ of soil) and phosphorus by $28.65 \%$ (amounted to $229 \mathrm{mg} / \mathrm{kg}$ of soil). Soil micronutrients actively used free soil nitrate nitrogen to decompose organic matter. The use of all preparations reduced the content of organic matter in the soil. Accordingly, if the goal is not to obtain a short-term high yield due to a rapid increase in effective fertility, it is necessary to use these microbiological fertilizers in combination with organic fertilizers of any formation green manure crops, plant residues, animal residues.

The content of trace elements in the soil is also an important parameter of effective fertility. The content of zinc, copper, boron increased in variants with micronutrients, compared with the control. This increase was especially significant in variants with soil biological fertilizers Agrinos 1 and Sterniphag SP. Here the content 
of trace elements increased by 20-60\% compared with the control. The zinc content increased by $2.29 \%$ and amounted to $1.115 \mathrm{mg} / \mathrm{kg}$ of soil, copper increased by $13.06 \%$ and amounted to $6.84 \mathrm{mg} / \mathrm{kg}$ of soil, boron increased by $30.4 \%$ and amounted to $0.785 \mathrm{mg} / \mathrm{kg}$.

The decomposition of pure plant material, that is linen, went faster on the variants with the use of biological preparations, as compared with the control. By the 3-month deadline for laying the linens, decomposition on the best variant with Ecorost humic preparation was $20.6 \%$. Variants with the preparations Biocomplex BTU and Sterniphag SP, were somewhat inferior and the decomposition was fixed at 13-14\%. In the variant with Agrinos 1, linen lost a little more than $8 \%$ in weight. The smallest biological activity of cellulose-decomposing bacteria was recorded on the control variant, where the decomposition of the linen did not exceed $5 \%$ in three months

The decomposition of winter wheat straw in the variants with microbiological preparations was higher compared with the control and increased on average by $15.47 \%$. The highest decomposition rate was shown by the samples after treatment with the Ecorost humic preparation and Agrinos 1 bacterial fertilizer (as of day 236 of the experiment). The use of biological fertilizers had some positive effect on the content of mobile forms of nitrogen, phosphorus and potassium.

When applying the working solution on the basis of biofungicide cellulose-steric Sterniphag SP with serial sprayers, the filter element was blocked, and when using AdU NGP as a fertilizer, blocking of the central filter was detected only with Ecorost humic preparation. As recommendations, it was suggested when filling the process tank to perform additional filtration of the working solution through filters with a cell size of not more than $0.150 \mathrm{~mm}$.

In general, AdU NGP as a fertilizer showed efficient operation and high reliability. This machine will be used when harvesting in 2019 in STIC "Agrotechnopark". In August 2019, the quality of the biological crop will be assessed. Thus, the best parameters for the decomposition of the crop residue were shown by:

- humic preparation Ecorost at a dosage of 0.4 1/ha;

- bacterial fertilizer Agrinos 1 at a dosage of 1 1/ha.

And the best parameters for increasing the content of trace elements in the soil showed:

- bacterial fertilizer Agrinos 1 in a dosage of 1 1/ha;
- biofungicide-cellulolytic Sterniphag SP in a dosage of 80 grams per hectare.

\section{References}

1. K.A. Macintosh, D.G. Doody, P.J.A. Withers, R.W. McDowell, D.R. Smith, L.T. Johnson, T.W. Bruulsema, V. O'Flaherty, J.W. McGrath, Sci. Total Environ. 1(649), 90-98 (2018) DOI: 10.1016/j.scitotenv.2018.08.272

2. H. Mu, S. Fu, B. Liu, B. Yu, A. Wang, Environ. Monit. Assess. 190(9), 504 (2018) DOI: 10.1007/s10661-018-6836-7.

3. I.V. Rusakova, Juvenis scientia 9, 4-9 (2018) DOI: 10.32415/jscientia.2018.09.01

4. W.L. Zhai, C.B. Yang, X.P. Zhang, G.B. Gao, Z.K. Zhong, Ying Yong Sheng Tai Xue Bao 29(4), 1147-1155 (2018) DOI: 10.13287/j.10019332.201804.006

5. G. Corti, D.C. Weindorf, M.J. Fernández Sanjurjo, H. Cacovean, Applied and Environmental, Soil Sci. 2012, 2 (2012) Article ID 204914, Retrieved from: https://doi.org/10.1155/2012/204914

6. G. Berg, C. Zachow, H. Müller, J. Phillips, R. Tilcher, Next-generation bio-products sowing the seeds of success for sustainable agriculture Agronomy 3, 648-656 (2013) DOI: 10.3390/agronomy3040648.

7. E.P. Polikarpova, I.E. Mizikovskiy, Preparing accounting information on costs for manufactured crop production Custos e Agronegocio 14(4), 149166 (2018)

8. R.N. Ushakov, A.V. Ruchkina, V.I. Levin et al., Sustainability of Agro-Gray Soil to Pollution and Acidification, and its Biodiagnostics Int. J. of Engin. and Technol. 7, 4.36, 929-934 (2018)

9. I.Yu. Bogdanchikov, D.V. Ivanov, N.V. Byshov, A.N. Bachurin, A.A. Kacharmin, Vestnik APK Stavropol'ya 4, 5-11 (2018) DOI: 10.31279/22229345-2018-7-32-5-11.

10. I.Yu. Bogdanchikov, N.V. Byshov, K.N. Drozhzhin, Collec. of sci. works of the XII Int. sci. and pract. Conf. 477-479 (2019) DOI: 10.23947/interagro.2019.6.477-479 